\title{
Corrigendum
}

\section{Corrigendum to "Improvement of Memory by Means of Ultra-Low Doses of Antibodies to S-100B Antigen"}

\author{
Evidence-Based Complementary and Alternative Medicine
}

Received 30 November 2020; Accepted 30 November 2020; Published 31 December 2020

Copyright @ 2020 Evidence-Based Complementary and Alternative Medicine. This is an open access article distributed under the Creative Commons Attribution License, which permits unrestricted use, distribution, and reproduction in any medium, provided the original work is properly cited.

In the article titled "Improvement of Memory by Means of Ultra-Low Doses of Antibodies to S-100B Antigen" [1], conflicts of interest should have been declared as follows. At the time of publication by OUP, the journal considered research on homeopathy, but no longer does.

\section{Conflicts of Interest}

The author Oleg Epstein is the founder and CEO of Materia Medica Holding Company and holds a relevant patent, "Curing method for pathologic syndrome and medicinal preparation” (US20030099636A1, 2003).

\section{References}

[1] O. I. Epstein, I. F. Pavlov, and M. B. Shtark, "Improvement of Memory by Means of Ultra-Low Doses of Antibodies to S-100B Antigen," Evidence-Based Complementary and Alternative Medicine, vol. 3, Article ID 973943, 5 pages, 2006. 